\title{
In love and struggle: letters in contemporary feminism
}

Margaretta Jolly, Columbia University Press, New York, 2008, pp. ix +315 , ISBN 978-0-231-13792-8, £23.50/\$40.00

Feminist scholars have done much to recoup literary forms and genres such as the diary and autobiography that have been devalued due to an association with women and the private sphere. However, as Margaretta Jolly notes, letters have remained a largely 'unsung literature' (p. 20). In In Love and Struggle, Jolly lifts her voice to amend this omission.

This book asserts the value of women's private and public correspondence, examining the role that letters and letter writing played in Anglo-American second-wave feminism. Taking a broadly chronological approach that moves from the 1970 s to the 1990s, Jolly examines the form, function and reception of a range of different types of letter: lesbian love letters through which women invented a new political identity, letters between mothers and daughters negotiating intergenerational conflict, farewell letters to men from women embracing separatism, epistolary fictions such as Alice Walker's The Color Purple, open letters expressing internal conflicts in the Women's Movement such as that between Audre Lorde and Mary Daly, chain letters and newsletters central to the Greenham peace campaign, letters from second wavers to third-wave feminists that constitute a kind of epistolary handbook, as well as email and new opportunities for communication engendered by cyberculture. Not just a means of communication, Jolly demonstrates that letters helped to construct an imagined community of women and reveal the way that women negotiated their changing relationships to each other, to men and to the movement, recording the loving alliances and angry disputes that shaped secondwave feminism.

Jolly shows that letters offer more than an intimate record of the Women's Movement, important though that is in its own right. Feminist epistolarity, she avers, embodies the values and ideals of a newly emergent and developing political consciousness. In particular, Jolly proposes that by prioritizing personal and political connections between women, by articulating an identity that is emphatically relational, and by dramatizing what she terms 'an ethics of care', letters reflect a feminist model of relationship. This last point, that an ethics of care integral to the culture of second-wave feminism finds specific expression in women's letters of the period, forms the book's central thesis and distinguishes it from other feminist studies of the form. Resisting sentimentalism, Jolly also highlights the often painful struggle between ideals and reality or individualism and collectivism, tracing women's fraught attempts to negotiate autonomy (taking care of oneself) with the commitment they make, as feminists, to care for women as a group. 
Another interesting argument pursued by this book rests on the assertion that there are special affinities between second-wave feminism and letter writing as a literary form; in other words, that there is a distinctively feminist epistolary discourse. Jolly does not contest the traditional association of letters with women's art; she notes that it is mostly women who archive family letters and suggests that failed relationships prompt women to write unsent letters or partake of the ritual destruction of letters. However, in contrast to the eighteenth-century stereotype of the woman writer that identified scribbling women with letters on the basis that both are objects of exchange in patriarchal economies, Jolly highlights the ways in which feminist consciousness transformed women's letter-writing into an anti-patriarchal practice. For example, she demonstrates that self-consciously inventive lesbian love letters reformed a genre traditionally associated with women's sexual enthrallment to men. Pondering whether or not email is a specifically feminist form of communication, she also proposes that the feminist ideals of caring and personalized exchange prevail in internet exchanges, contributing to what she calls a woman-centred epistolary ethics. The foundational feminist axiom 'the personal is political' underlies the value that Jolly ascribes to letters as a private, domestic form of women's art, one that affirms the importance of the everyday and women's emotional lives. Yet, at the same time, her focus on open letters, the role that letters have played in campaigning, and new, digital forms of exchange via the internet challenge the common association of letters with the private sphere.

The question of ethics interweaves the book's thirteen chapters, unifying the discussion of different kinds of correspondence, and Jolly ends by reflecting on the ethical dilemmas of publishing letters: making public exchanges that were intended to be private, publishing only one side of an exchange, and publishing without informed consent. Although she does discuss letters discovered in archives such as the Lesbian Herstory Archives in Brooklyn, these fraught ethical issues may explain why Jolly relies mostly on previously published collections and few actual letters appear in the book.

In Love and Struggle will appeal to anyone interested in women's history, particularly the history of the Women's Movement, feminist literary critics concerned with marginalized forms of writing, and those who simply enjoy reading other people's missives, although the plain nosey may be disappointed by the limited number of letters included here. Overall, Jolly's study makes an important contribution to the history of second-wave feminism and offers valuable new insights into letter writing as a feminist literary practice.

Emma Parker

doi: $10.1057 / f r .2009 .13$ 